\title{
Novel $\alpha$-Amylases Amy A1 and Amy A2 from digestive tract of tropical house cricket Gryllodes sigillatus (Orthoptera: Gryllidae): hydrolysis and transglycosylation reactions
}

\section{Eugène Jean Parfait Kouadio ${ }^{1}$, Hubert Kouassi Konan ${ }^{1}$, Fabrice Achille Tetchi ${ }^{\star}{ }^{\star}$, David Brou Kouakou ${ }^{3}$ and Lucien Patrice Kouamé ${ }^{1}$}
${ }^{1}$ Laboratory of Biochemistry and Food Technology, University of Abobo Adjamé, UFR/STA, 02 BP 801 Abidjan 02 (Côte d'Ivoire).
${ }^{2}$ Laboratory of Food Biochemistry and Tropical Products Technology; University of Abobo Adjamé, UFR/STA, 02 BP 801 Abidjan 02 (Côte d'Ivoire).
${ }^{3}$ Laboratory of Nutrition; University of Abobo Adjamé, UFR/STA, 02 BP 801 Abidjan 02 (Côte d'Ivoire)

\begin{abstract}
The aim of the study was to investigate the ability of Amy A1 and Amy A2 a-amylases from digestive tract of the tropical house cricket Gryllodes sigillatus to hydrolyse the gelatinized starches of some tropical crops and their potentiality to catalyze tranglycosylation reactions. The Amy A1 and Amy A2 a-amylases hydrolyzed efficiently the starches from tubers (yam, cocoyam) and roots (cassava) to obtain reducing sugars content ranging from $22.2 \mu \mathrm{g}$ to $62.1 \mu \mathrm{g}$ after 6 hours incubation. However, the both $\alpha$-amylases hydrolyzed less the starches from cereal (maize, millet). Otherwise, they catalyzed the transglycosylation reactions with soluble starch as donor and phenol as acceptor. The optimisation of the transfer product yield was studied as functions of $\mathrm{pH}$, incubation time, concentration of donor and acceptor. Indeed, the obtained yield in experimental optimum conditions were $63.1 \pm 0.27 \%$ and $51.6 \pm 0.03 \%$ for Amy A1 and Amy A2 $\alpha$-amylases respectively. On the basis of these results, $\alpha$-amylases from the digestive tract of the cricket $G$. sigillatus appear to be a valuable tool for the glycosylation of phenolic compounds.
\end{abstract}

Keywords: Enzyme, starch, hydrolysis, tranglycosylation, G. sigillatus.

\section{INTRODUCTION}

$\alpha$-amylases ( $\alpha-1,4-\mathrm{D}$-glucan glucanhydrolases, E.C. 3.2.1.1) are enzymes that catalyze the hydrolysis of internal $\alpha-1,4$ linkages of starch molecules acting through a "retaining mechanism" (Sinnott, 1990) and belong to family 13 of glycosyl hydrolases (GH13). The a-amylases are widely distributed in nature and have found multiple applications in industry (Thippeswamy et al., 2006; Moreno et al., 2010).

Nowadays, because of their uses in food, brewing, textile, detergent, pharmaceutical and fine chemistry industries, enzymatic hydrolysis of starch into maltooligosaccharides is very important. Enzymatic hydrolysis of starch is preferred to the older and more traditional method of acidic hydrolysis because of the easy conditions of its realisation (lower temperatures, normal pressure and $\mathrm{pH}$ of the medium around 6-8) (Kolusheva and Marinova, 2007). Indeed, starch enzymatic hydrolysis is characterized by a high reaction rate. Moreover, several studies were reported on the hydrolysis on starches from tropical tubers and roots (Valetudie et al.,1993; Adebiyi et al., 2005; Omemu et al., 2005) and cereals (colonna et al., 1988; Matsubara et al., 2004)

In addition to hydrolysis reactions, some $\alpha$-amylases as many other glycosyl hydrolases also catalyse various types of transglycosylation reactions. In general, these reactions proceed via a glycosylenzyme intermediate, which is deglycosylated either by water (hydrolysis) or another glycosyl acceptor (transglycosylation). Thus, many a-amylases have been examined as catalysts for glycosylation of various phenolic compounds (Nishimura et al., 1994; Park et al., 1999) and alcohols (Moreno et al., 2010; Santamaria et al., 1999; Larsson et al., 2005). Concerning particularly insect digestive tract, some 
glycosidases were explored in tranglycosylation reaction (Kouamé et al., 2001; Yapi et al., 2007).

In previous study, Kouadio et al. (2010) purified and Characterized two Dimeric $\alpha$-amylases from Digestive Tract in the Tropical House Cricket Gryllodes sigillatus (Orthoptera: gryllidae). The two Dimeric a-amylases were Amy A1 and Amy A2. According to this author, Amy A1 showed an optimum $\mathrm{pH}$ of 6.6, whereas for Amy $\mathrm{A} 2$, the optimum $\mathrm{pH}$ was 7.0. Both $\alpha$-amylases exhibited optimum temperature at $55^{\circ} \mathrm{C}$. Amy A1 was found to be stable at $\mathrm{pH} 6.0$ to 7.6 and up to $50^{\circ} \mathrm{C}$. Amy $\mathrm{A} 2$ was found to be stable at $\mathrm{pH} 6.6$ to 7.6 and also up to $50{ }^{\circ} \mathrm{C}$. The two enzymes retained over $95 \%$ of their maximum activity at $37^{\circ} \mathrm{C}$ after $3 \mathrm{~h}$ (Kouadio et al., 2010). From a physiological point of view, $\alpha$ amylases Amy A1 and Amy A2 play a fundamental role in energy production for this insect. Consequently, the digestive tract of this insect could be a good source of a-amylases for starch saccharification.

To the best of our knowledge, no study has so far been carried out to evaluate an insect $\alpha$-amylase with transglycosidase activities. Hence, the objective of this study was to investigate the ability of these $\alpha$ amylases from digestive tract of tropical house cricket $G$. sigillatus to hydrolyse various starches from tropical crops and their potentiality to catalyze tranglycosylation reactions.

\section{MATERIALS AND METHODS}

\section{Sample collection of raw materials}

Cricket collection: The crickets ( $G$. Sigillatus) were collected from the garden of Abobo-Adjamé University (Abidjan, Côte d'Ivoire). The insects (an equal proportion of each sex) were kept without feed for 24 hours, after which they were stored at $-20^{\circ} \mathrm{C}$ until analysis.

Enzyme: The Amy A1 and Amy A2 a-amylases used for hydrolysis and transglycosylation reactions originated from the purified enzymes collection of "Laboratory of Biochemistry and Food Technology, University of Abobo Adjamé, UFR/STA (Abidjan, Côte d'Ivoire)". The a-amylases were purified as described previously by Kouadio et al (2010).

Plant material: The tubers of yams (Dioscorea alata ("Bètè-bètè" cultivar), Dioscorea cayenensisrotundata ("Krenglè" cultivar), cocoyams (Xanthomonas sagittifolium), ginger (Zingiber officinale, the cassava roots ("sweet" and "bitter" cultivars) (Mannihot esculenta), the maize ("red" and "white" cultivars) (Zea mays) and the millet (Pennisetum glaucum) were purchased at Yopougon Market (District d'Abidjan, Côte d'Ivoire).

Enzyme extraction: The enzymatic crude extract was prepared according the procedure described previously kouadio et al (2010). The Adult crickets were washed in distilled water, before the digestive tract was dissected out.Then, the digestive tract (10 g) was homogenised in $20 \mathrm{ml}$ of phosphate buffer (100 mM; pH 6,6) containing $\mathrm{NaCl} 0.9 \%$ (w/v) with a MICROCRUSHER ULTRATURAX (type TP 10/18). The homogenate was subjected to sonication using a TRANSSONIC T420 for $10 \mathrm{~min}$ and then centrifuged at $6000 \mathrm{rpm}$ for $20 \mathrm{~min}$ at $4{ }^{\circ} \mathrm{C}$. The gotten supernatant was used as the crude extract and conserved at $4{ }^{\circ} \mathrm{C}$.

Enzyme purification: The $\alpha$-amylases were purified as described previously by Kouadio et al. (2010). All purification steps were carried in the cold room. The crude extract $(15 \mathrm{ml})$ was saturated with $80 \%$ ammonium sulphate at $4{ }^{\circ} \mathrm{C}$ and left with slow stirring for $24 \mathrm{~h}$. The suspension was centrifuged for $30 \mathrm{~min}$ at $6,000 \mathrm{~g}$. The precipitated protein was dissolved in $1 \mathrm{ml}$ of $20 \mathrm{mM}$ phosphate buffer $\mathrm{pH} 6.6$ and then loaded onto a $1.6 \times 65 \mathrm{~cm}$ sephacryl S-100 HR column equilibrated with $100 \mathrm{mM}$ phosphate buffer $\mathrm{pH}$ 6.6. The flow rate was $20 \mathrm{ml} / \mathrm{h}$ and fractions of 1 $\mathrm{ml}$ were collected. The fractions containing amylase activity were pooled. These amylase fractions were then loaded onto a $2.2 \times 7.3 \mathrm{~cm}$ DEAE-sepharose CL-6B column equilibrated with the same buffer. Unbound proteins were removed by washing the gel with $60 \mathrm{ml}$ of equilibration buffer. Bound proteins were then eluted over a stepwise gradient $(0.2$ and 1 M) $\mathrm{NaCl}$, in $60 \mathrm{ml}$ of equilibration buffer. The flow rate was $103 \mathrm{ml} / \mathrm{h}$ and fractions of $2 \mathrm{ml}$ were collected. Pooled unbound amylase activity (Peak 1) was saturated to a final concentration of $1.7 \mathrm{M}$ sodium thiosulphate and added to a $1.4 \times 5 \mathrm{~cm}$ PhenylSepharose 6 Fast-flow column previously equilibrated with $20 \mathrm{mM}$ phosphate buffer $\mathrm{pH} 6.6$ containing $1.7 \mathrm{M}$ sodium thiosulphate. The column was washed with the equilibration buffer and the proteins retained then eluted with a reverse stepwise gradient of sodium thiosulphate concentration (from 1.7 to $0 \mathrm{M}$ ) in the same phosphate buffer at a flow rate of $69 \mathrm{ml} / \mathrm{h}$. Fractions of $1 \mathrm{ml}$ were collected. The active fractions were pooled and dialyzed overnight against a $20 \mathrm{mM}$ phosphate buffer $\mathrm{pH}$ 6.6. These fractions were regarded as the purified enzyme. Bound amylase activity (Peak 2) eluted from DEAE-sepharose CL-6B was also saturated to a final concentration of $1.7 \mathrm{M}$ 
sodium thiosulphate and loaded onto the same Phenyl-Sepharose column, as described above. The active fractions were pooled and dialyzed overnight against a $20 \mathrm{mM}$ phosphate buffer $\mathrm{pH}$ 6.6. Again, these fractions were regarded as the purified enzyme.

Starches from Tropical Crops isolation: Starches from Tropical Crops were extracted according to the procedure described by Amani et al. (2002). The tubers and roots $(200 \mathrm{~g})$ were weighed, washed and peeled. After peeling, they were cut up into small slices $(4 \times 4 \mathrm{~cm})$ with stainless steel knife and steeped in distilled water containing $0.1 \%(\mathrm{w} / \mathrm{v})$ sodium metabisulphite. The slices were ground in a grinder (Moulinex, Lyon-France) and the paste recovered in $4 \%(\mathrm{w} / \mathrm{v})$ sodium chloride solution to separate proteins from the starch during $24 \mathrm{~h}$ at $25 \pm 1^{\circ} \mathrm{C}$. As for the maize and the millet $(200 \mathrm{~g})$ were weighed, washed and ground in previously condition. Each slurry was sieved successively through $750 \mu \mathrm{m}, 150$ $\mu \mathrm{m}$ and $100 \mu \mathrm{m}$ sieves. Then, the starches were alternatively decanted and washed at least four times with distilled water. The starch suspensions were oven-dried at $45{ }^{\circ} \mathrm{C}$ for $48 \mathrm{~h}$ [Mettenter (MMM) Venticell (Brno-Czech republic)]. The dry products were ground, quantified and then stored for analyses.

Chemicals: Soluble starch, phenol and phenylphosphate were purchased from Sigma Aldrich. Silicate gel for thin-layer chromatography (TLC) was obtained from Merck. All other chemicals and reagents are commercially available and of analytical grade.

Thin Layer Chromatography (TLC) Analysis of Products from Soluble Starch Enzymatic Hydrolysis by a-Amylases Amy A1 and Amy A2 : Enzymatic Hydrolysis was carried out according the method of Brückner (1955). Hydrolysis of soluble starch by Amy A1 and Amy A2 a-amylase was tested with $50 \mu \mathrm{l}$ of purified amylase mixed with $170 \mathrm{ml}$ of phosphate buffer (100 mM; pH 6.6) and $80 \mu \mathrm{l}$ of 0.5 $\%$ starch at $37{ }^{\circ} \mathrm{C}$ for 2 and $6 \mathrm{~h}$. Concurrently, aliquots $(5 \mu \mathrm{l})$ were removed and spotted onto a TLC plate. Hydrolyzed products were separated using butanol-acetic acid-water 9: 3.75: $2.25(\mathrm{v} / \mathrm{v} / \mathrm{v})$ and developed using naphto-resorcinol in ethanol and $\mathrm{H}_{2} \mathrm{SO}_{4} 20 \%(\mathrm{v} / \mathrm{v})$. The sugar spots were visualised keeping the plate at $110^{\circ} \mathrm{C}$ for $5 \mathrm{~min}$. The observed products were identified in relation to the control treated in the same conditions.

Hydrolysis of Gelatinized Starch: This study involved the starches previously gelatinized by heating each solution of starch $(1 \% \mathrm{w} / \mathrm{v})$ for $30 \mathrm{~min}$ at $100{ }^{\circ} \mathrm{C}$ under gentle stirring. Then, the ability of Amy A1 and Amy A2 a-amylases to hydrolyse gelatinized starch was studied using tuber (yam, cocoyam), root (cassava, ginger) and cereal (maize, millet) starches. Each Enzyme solution (400 and $250 \mu \mathrm{l}$ for Amy A1 and Amy A2 respectively) containing $18 \mu \mathrm{g}$ of proteins, $400 \mu \mathrm{l}$ of the gelatinized starch solutions and appropriate volume of phosphate buffer ( $\mathrm{pH} \mathrm{6.6)}$ to adjust the medium to $1500 \mu \mathrm{l}$, were incubated at $37^{\circ} \mathrm{C}$ for $0.5 ; 1 ; 2$ and $6 \mathrm{~h}$. The reaction was stopped by addition of $300 \mu$ 3,5-dinitrosalicylic acid (DNS) and heating in boiling water for $5 \mathrm{~min}$. The absorbance was read at $540 \mathrm{~nm}$ after cooling on ice for $5 \mathrm{~min}$. The reducing sugar content produced was determined by the 3,5-dinitrosalicylic acid method (Bernfeld, 1955), using maltose as the standard.

Transglycosylation Reactions: The ability of Amy $\mathrm{A} 1$ and Amy A2 a-amylases from the digestive tract of tropical house cricket $G$. sigillatus to catalyze transglycosylation reactions was tested with soluble starch as donor and phenol as acceptor.

In typical experiment, transglycosylation reactions were carried out at $37^{\circ} \mathrm{C}$ in a total mixture $(1.5 \mathrm{ml})$ containing phosphate buffer $(100 \mathrm{mM}$; pH 6.6), each a-amylase $(3.7 \mu \mathrm{g})$, concentrations of glycosyl donor (soluble starch) ranging from $0,25 \%$ to $3 \%$ and glycosyl acceptor (phenol) varying of $2,5 \mathrm{mM}$ à 25 $\mathrm{mM}$. The progress of reaction was monitored at times ranging from 1 hour to 11 hours by withdrawing aliquots $(100 \mathrm{ml})$ which were heated at $100^{\circ} \mathrm{C}$ for 5 min. After filtration through hydrophilic Durapore membrane (Millipore, $0.22 \mu \mathrm{m}$, Billerica, MA, USA), the reaction mixture $(20 \mathrm{ml})$ was analyzed quantitatively by HPLC at room temperature. Phenylphosphate $(1 \mathrm{mM})$ was used as the internal standard to correct chromatographic product areas. The column used was VARIAN RP 18 RES ELUT $5 \mu$ C18 90A (150 X $4.60 \mathrm{~mm}$ ) and phenolic compounds were detected at $257 \mathrm{~nm}$ with a SPECTRASYSTEM UV 1000 detector. The elution was done with a BECKMAN 114M solvent delivery module pump, at a flow rate of $0.3 \mathrm{ml} / \mathrm{min}$ using degassed acetonitrile/water in the ratio $1: 1(\mathrm{v} / \mathrm{v})$ as eluent. The chromatograms were obtained with a SHIMADZU CR8A CHROMATOPAC V1.04 integrator. The yield of transglycosylation was estimated compared with the reduction of phenol area. Thus, the yield of transglycosylation was calculated as follow: phenol initial area-phenol residual area/phenol initial area $X$ 100 (\%), 
where phenol initial area correspond to the area of phenol in the medium without enzyme ( $\alpha$-amylase Amy A1 or Amy A2) and phenol residual area is the area of phenol in the medium containing $\alpha$-amylase Amy A1 or Amy A2.

Statistical analysis: All analyses were performed in triplicates. Statistical significance was established using Analysis of Variance (ANOVA) models to estimate the hydrolysis products and the transglycosylation yields. Means were separated according to Duncan's multiple range analysis $(P \leq 0.05)$, with the help of the software Statistica 7.1 (StatSoft Inc, Tulsa USA Headquarters).

\section{RESULTS}

Products Profile of Soluble Starch Hydrolysis by a-Amylases Amy A1 and Amy A2: The profile of products after soluble starch hydrolysis by Amy $A 1$ and Amy A2 $\alpha$-amylases was carried out on TLC (Fig 1: $A$ and $B$ ). The reducing sugars produced by both $\alpha$-amylases action on soluble starch were essentially maltose, maltotriose and probably maltotetraose.
A

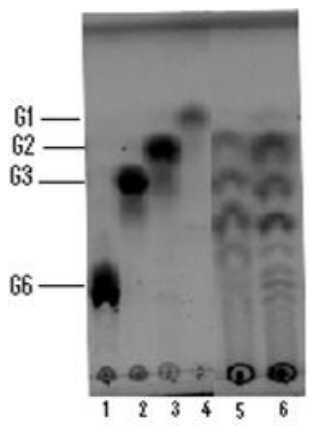

B

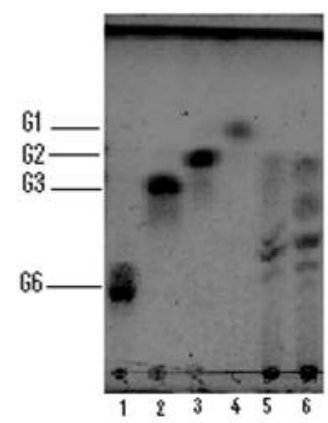

Fig 1: Thin layer chromatography of the products of hydrolysis obtained from soluble starch $0.5 \%$, by $\alpha$ amylases Amy A1 (A) and Amy A2 (B) from digestive tract of $G$. sigillatus. (A) and (B): lane 1, maltohexaose (G6); lane 2, maltotriose (G3); lane 3, maltose (G2); lane 4, glucose (G1); lane 5, hydrolytic products after $2 \mathrm{~h}$ ( $A$, Amy $A 1$ and $B$, Amy $A 2)$; lane 6, hydrolytic products after $6 \mathrm{~h}$ (A, Amy A1 and B, Amy A2).

Hydrolysis of Gelatinised Starch: The ability of the a-amylases Amy A1 and Amy A2 of cricket G. sigillatus to digest different gelatinized starches was studied using different tuber (yam, cocoyam and ginger), root (cassava,) and cereal (maize (red and white) and millet) starches. The results are summarised on Fig 2 to 4. A general increase of reducing sugar contents was observed during incubation time. Besides, Amy A1 and Amy A2 aamylases were able to hydrolyse the tuber starches studied (Fig.2A and 2B). The starch belonging to "bètè bètè" cultivar yam was fast hydrolysed by after 6 hours. So, the reducing sugar contents were of $57.7 \mu \mathrm{g}$ and $51.3 \mu \mathrm{g}$ for Amy A1 and Amy A2 $\alpha-$ amylases respectively. It was followed by cocoyam starch $(53.3 \mu \mathrm{g})$, yam "klenglè" starch $(33.2 \mu \mathrm{g})$ for Amy A1 and yam "klenglè" starch $(44.4 \mu \mathrm{g})$, cocoyam starch $(28.7 \mu \mathrm{g})$ for Amy A2. Otherwise, Amy $1 \alpha-$ amylase was hydrolysed the gelatinized starch tuber more quickly than the Amy 2 a-amylase.

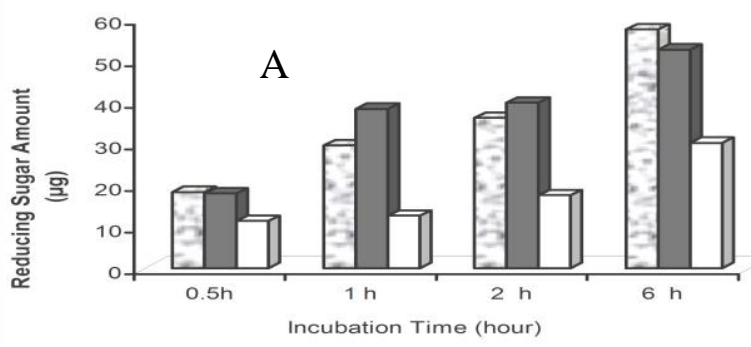

口Yam bètè-bètè $\square$ Cocoyam $\square$ Yam klenglè

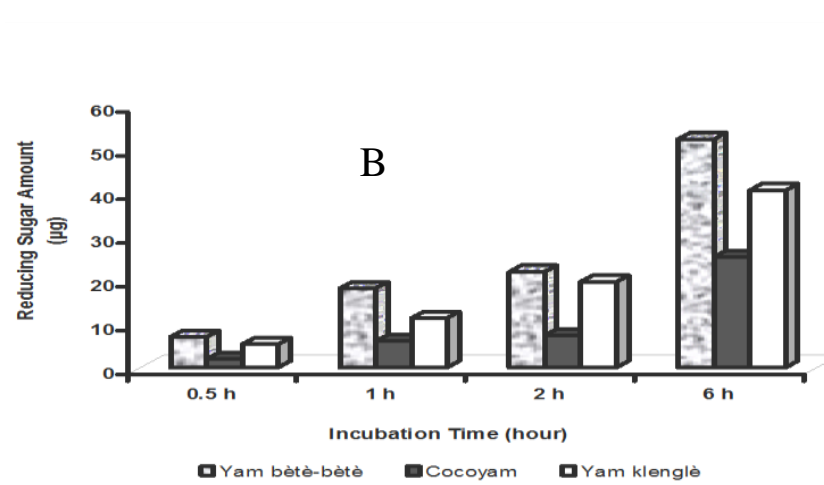

Fig 2: Hydrolysis of gelatinised starches from tuber (yam and cocoyam) by $\alpha$-amylases Amy A1 and Amy A2 from digestive tract of $G$. sigillatus.(A. Amy A1, B Amy A2) 

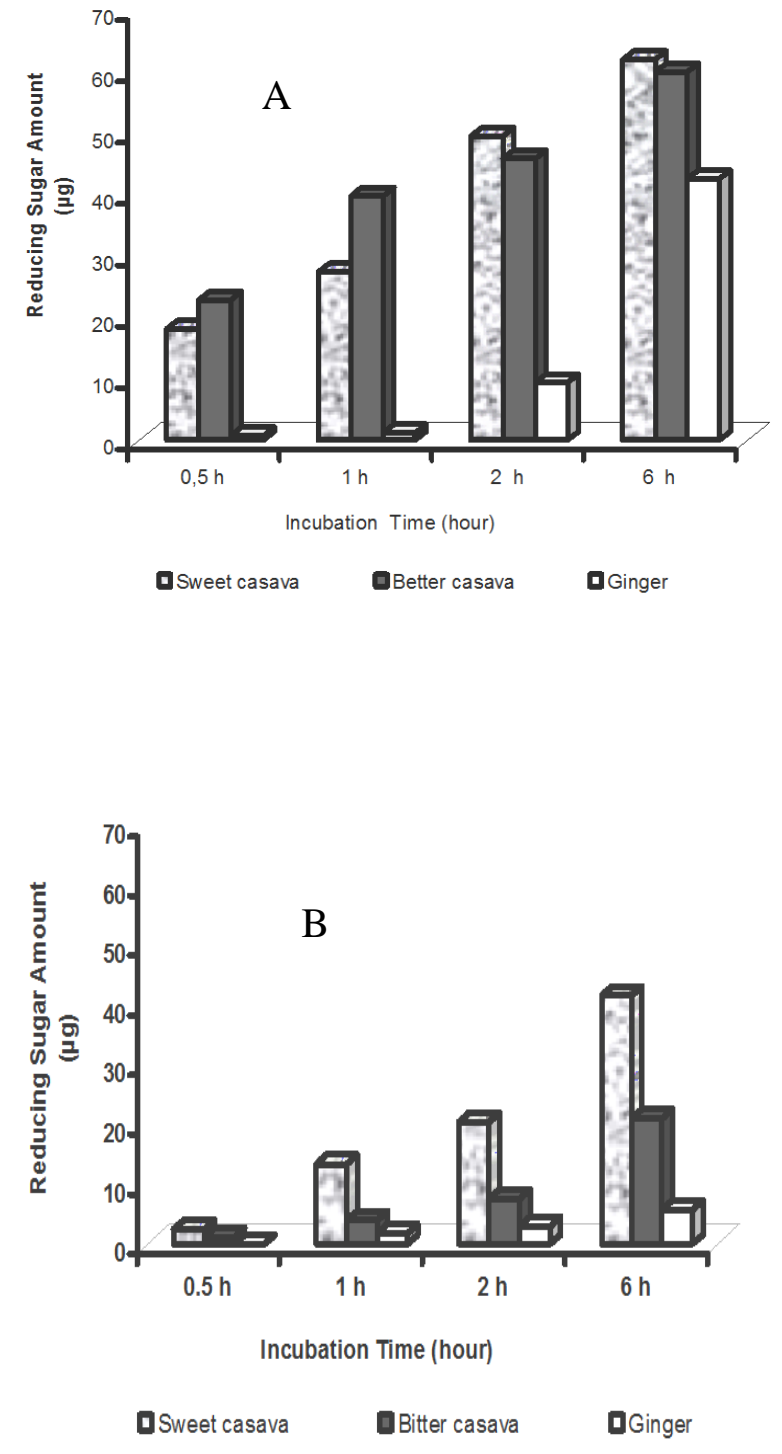

Fig 3: Hydrolysis of gelatinized starches from root (cassava and ginger) by $\alpha$-amylases Amy A1 and Amy A2 from digestive tract of $G$. sigillatus. (A. Amy A1, B Amy A2)

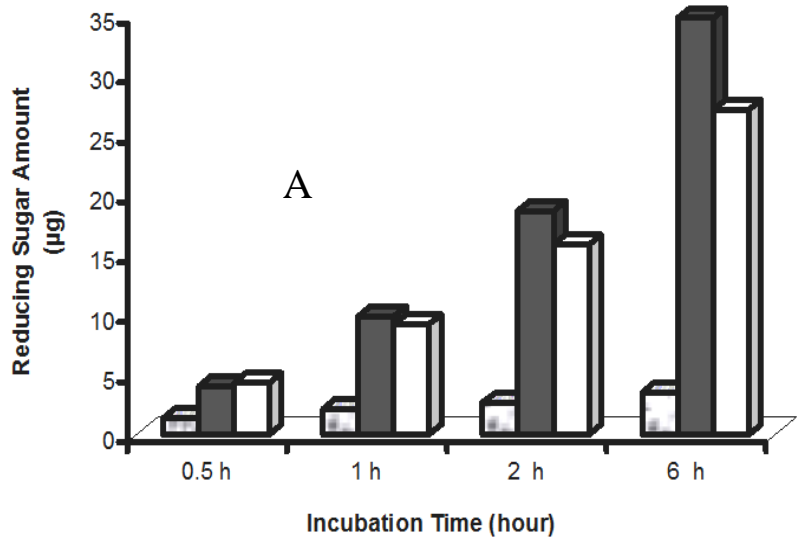

QRed maïze $\quad$ White maïze $\quad$ Millet

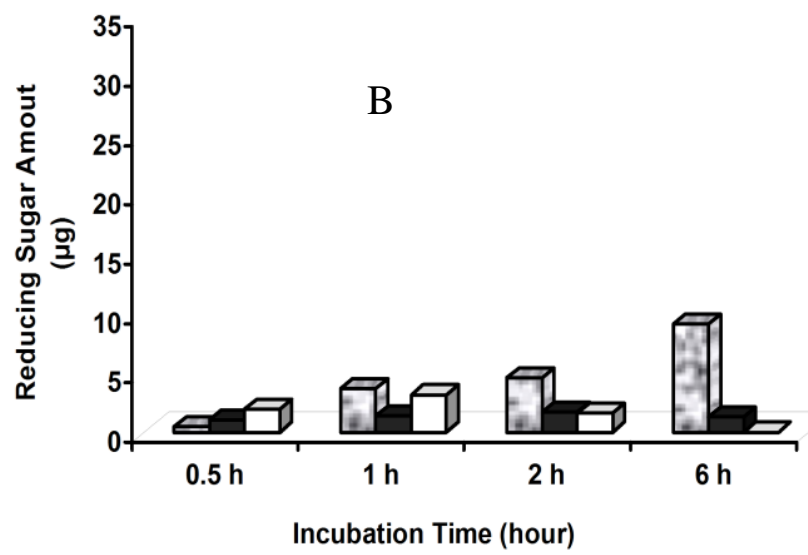

口White maïze $\quad$ Red maïze $\quad$ Millet

Fig 4: Hydrolysis of gelatinized starches from cereal (maize and millet) by $\alpha$-amylases Amy A1 and Amy A2 from digestive tract of $G$. sigillatus.( A. Amy A1, B Amy A2) 
Concerning the roots starches examined, the results (Figs. 3A and 3B) indicated that theses starches were overall more susceptible to hydrolysis by a-amylase Amy A1 when compared to their hydrolysis by aamylase Amy A2. Sweet cassava and bitter cassava starches were respectively hydrolyzed by Amy A1 and Amy A2 a-amylases. The obtained reducing sugar contents differed significantly at 0.05 level from one enzyme to another. So, they were $60.1 \mu \mathrm{g}$ and $62.1 \mu \mathrm{g}$ for sweet cassava and bitter cassava respectively after 6 hours incubation. As for hydrolysis of theses roots starches by a-amylase Amy A2 after 6 hours, better cassava starch was more hydrolyzed $(41.6 \mu \mathrm{g})$ than sweet cassava starch $(22.2 \mu \mathrm{g})$. Otherwise, ginger starch was fairly hydrolysed by $\alpha$-amylase Amy A1 (43.7 $\mu \mathrm{g})$ but it was least hydrolysed by $\alpha$-amylase Amy A2 $(5 \mu \mathrm{g})$. The Amy 1 a-amylase was hydrolysed the gelatinized starch tuber more quickly than the Amy 2 a-amylase. The both enzyme hydrolysed less the gelatinized starch of ginger.

The results of cereal starches hydrolysis was shown on Fig. 4A and 4B. The starches from red cultivar of maize and millet were fast hydrolysed by Amy A1 $\alpha$ amylase. After 6 hours incubation, the reducing sugar contents were $34.8 \mu \mathrm{g}$ with red cultivar of maize. The Amy A2 hydrolysed less the gelatinized starch from red cultivar of maize and millet. The obtained reducing sugar contents with two starches were lower to $5 \mu \mathrm{g}$. Otherwise, the both enzymes hydrolysed less the gelatinized starches from white maize cultivar. Indeed, the obtained reducing sugar content with this starch was $9.2 \mu \mathrm{g}$ for Amy A2 $\alpha$-amylase after 6 hours incubation.

Potentiality of the a-Amylases Amy A1 and Amy A2 to Catalyze Transglycosylation Reactions: $\alpha$ amylases Amy A1 and Amy A2 from digestive tract of G. sigillatus were assayed for their ability to catalyze tranglycosylation reactions with starch as glycosyl donor and phenol as glycosyl acceptor. Analysis of the reaction mixture by high-performance liquid chromatography (Fig. 5) has confirmed this ability. The chromatogram (Fig. 5B) showed three peaks of newly synthesized product (transfer product) with a retention time of $4.133,5.016$ and $6,204 \mathrm{~min}$, sited between these of the artefact $(1.021 \mathrm{~min})$ and the internal standard (phenylphosphate, $7.153 \mathrm{~min}$ ). In this context, the experimental conditions were optimized in relation those physicochemical parameters able to have an influence on tranglycosylation yield.
The $\mathrm{pH}$ influence on the yield of the transglycosylation was studied by using different $\mathrm{pH}$ ranging from 3.6 to 8.0 of phosphate buffer. The Highest yields were 63.1 and $51.6 \%$ and they were obtained at $\mathrm{pH} 4.6$ for $\alpha$-amylases Amy A1 and Amy A2 respectively (Table 1 ). The yields of transglycosylation differed significantly $(P \leq 0.05)$ during the $\mathrm{pH}$ variation and one enzyme to another Transglycosylation kinetics were also studied as a function of incubation time. The yields (\%) of glycosylation obtained at various times $(\mathrm{min})$ are shown in Fig.6.The optimum times of transglycosylation were $6 \mathrm{~h}$ for Amy $\mathrm{A} 1$ and $7 \mathrm{~h}$ for Amy A2.

Table 1: Influence of $\mathrm{pH}$ on the yields of transglycosylation reaction catalyzed by $\alpha$-amylases, Amy A1 and Amy A2 from the digestive tract of house cricket Grillodes sigillatus

\begin{tabular}{|c|c|c|}
\hline \multirow{2}{*}{$\mathbf{p H}$} & \multicolumn{2}{|c|}{ Yield of transglycosylation (\%) } \\
\cline { 2 - 3 } & Amy A1 & Amy A2 \\
\hline 3.6 & $47.0 \pm 0.11^{\mathrm{T}}$ & $41.0 \pm 0.22^{\mathrm{h}}$ \\
\hline 4.0 & $52.3 \pm 0.45^{\mathrm{o}}$ & $42.0 \pm 0.03^{1}$ \\
\hline 4.6 & $63.1 \pm 0.27^{\mathrm{p}}$ & $51.6 \pm 0.03^{\mathrm{n}}$ \\
\hline 5.0 & $51.1 \pm 0.43^{\mathrm{m}}$ & $43.1 \pm 0.05^{\top}$ \\
\hline 5.6 & $45.0 \pm 0.21^{\mathrm{k}}$ & $41.0 \pm 0.26^{\mathrm{h}}$ \\
\hline 6.0 & $35.0 \pm 0.5^{\mathrm{g}}$ & $33.0 \pm 0.24^{\dagger}$ \\
\hline 6.6 & $33.0 \pm 0.13^{\mathrm{i}}$ & $30.0 \pm 0.33^{\mathrm{e}}$ \\
\hline 7.0 & $30.0 \pm 0.15^{\mathrm{e}}$ & $28.0 \pm 0.28^{\mathrm{d}}$ \\
\hline 7.6 & $27.0 \pm 0.54^{\mathrm{c}}$ & $25.0 \pm 0.27^{\mathrm{b}}$ \\
\hline 8.0 & $25.0 \pm 0.27^{\mathrm{D}}$ & $23.0 \pm 0.11^{\mathrm{a}}$ \\
\hline
\end{tabular}

The obtained values are averages \pm standard deviation of triplicate determination

On the columns and lines of each parameter, the averages affected of no common letter are significantly different between them on the threshold of 5\% according to the test of Duncan

The Fig. 7 and 8 showed that the efficiency of the $\alpha-$ amylases from the digestive tract of the tropical house cricket $G$. sigillatus in catalyzing of transglycosylation reactions was also largely dependent on the respective concentrations of glycosyl donor (starch) and glycosyl acceptor (phenol). The highest yield of transglycosylation was obtained with a concentration of $2 \%$ of starch and $7.5 \mathrm{mM}$ of phenol for Amy A1. As For Amy A2, the highest yield was observed with $1.25 \%$ of starch and also $7.5 \mathrm{mM}$ of phenol. 


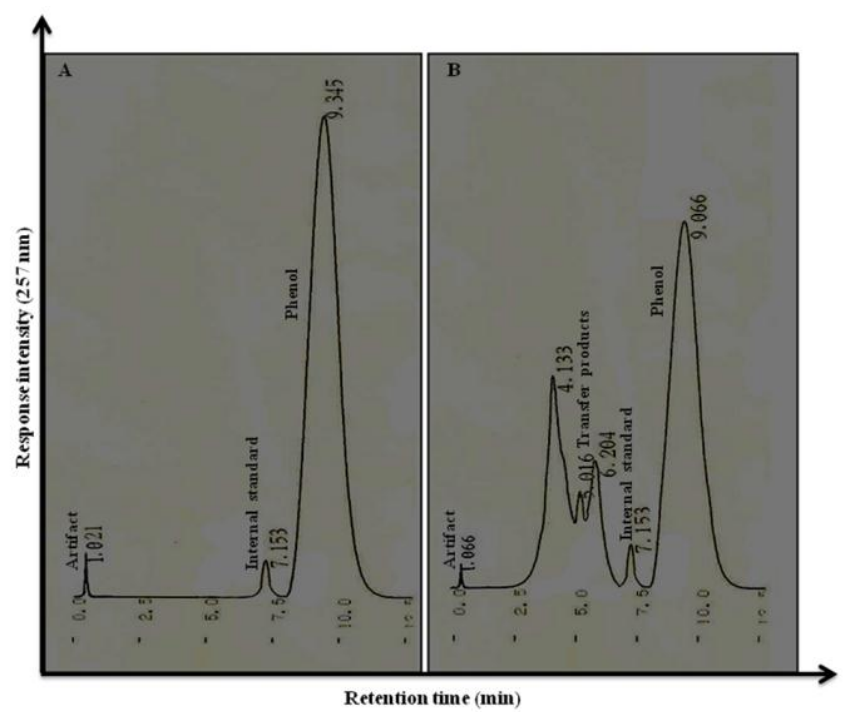

Fig 5: HPLC chromatograms of the typical transglyccosylation assay catalyzed by $\alpha$-amylases Amy $A 1$ and Amy A2 from digestive tract of $G$. sigillatus. A control, B assay

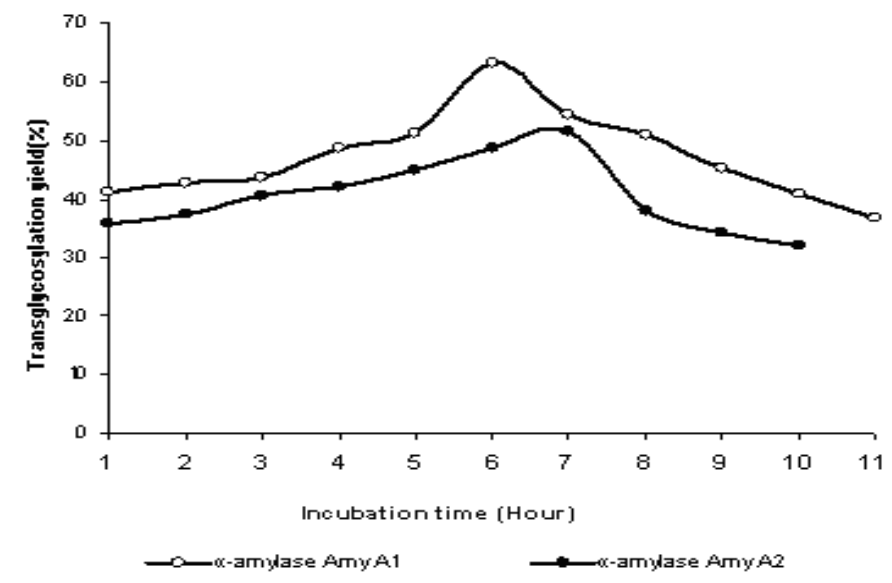

Fig 6: Time course of transglycosylation reaction catalyzed by $\alpha$-amylases Amy A1 and Amy A2 from the digestive tract of $G$. sigillatus

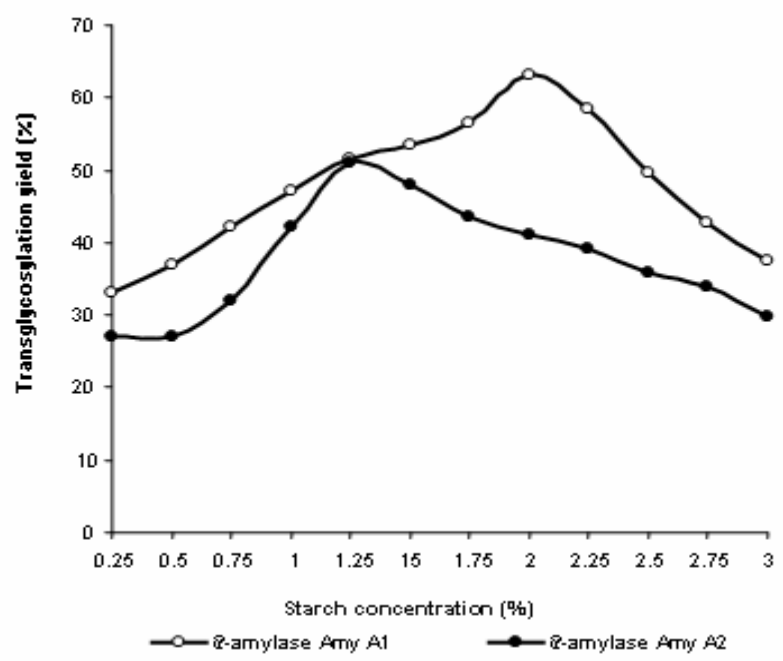

Fig 7: Effect of the glyccsyl donor (starch) concentration on transglycosylation reaction catalysed $\alpha$-amylases Amy A1 and Amy A2 from the digestive tract of G. sigillatus.

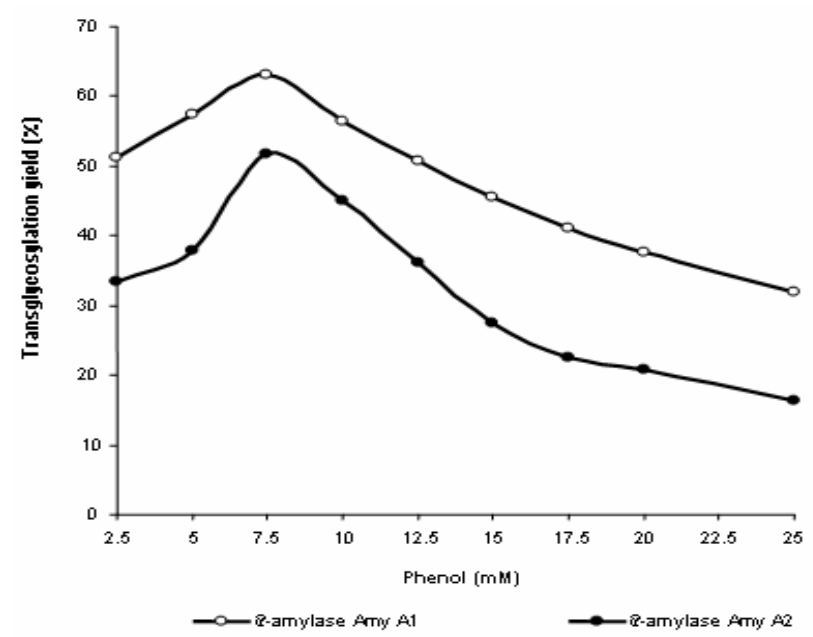

Fig 8: Effect of the glyccsyl acceptor (phenol) concentration on transglycosylation reaction catalysed a-amylases Amy A1 and Amy A2 from the digestive tract of $\mathrm{G}$. sigillatus.

\section{DISCUSSION}

The analysis of hydrolytic products after soluble starch hydrolysis by a-amylases from cricket $G$. sigillatus digestive tract on TLC revealed that maltose, maltotriose and probably maltotetraose were the major products. This means that theses amylolytic enzymes were endoamylases. Indeed, 
Amy A1 and Amy A2 a-amylases could be used in the production of syrup of oligosaccharides mixture.

The research works were carried out on gelatinised starches hyrolyses of tubers, roots, cereal and banana (Konsula and Liakopoulou-Kyriakides, 2004). This treatment increased the sensibility of starches during their enzymatic degradation (Noda et al., 2008). According to Guilbot and Mercier (1962), the slight sensibility of native starches would be due to the existence of concentric layers around the grain presenting different resistances to the enzymatic attack. As for gelatinized starches, their sensibility to the amylolytic enzymes inscreased by the loss of the crystalline structure (Bornet, 1992). Our results were similar to those obtained by using pancreatic amylase of swine (Valetudie et al., 1993), of the bacteria Bacillus claussi (Noda et al., 2008) and of cockroach (Periplaneta. Americana) (Kouamé et al., 2004). On the other hand, the results differed to those reported by using fungal amylase of Pichia burtonii (Takeuchi et al., 2006). This situation suggested that the catalytic efficiency of the amylases to the starch hydrolysis would be closely bound to their botanical origin (Favier, 1969; Delpeuch and Favier, 1980; Okolo et al., 1995) and to enzyme origin (Hamilton et al., 1999). The ability of Amy A1 and Amy A2 amylases to hydrolyze the tubers and roots starches was remarkable property. Indeed, this food was produced in very big quantity in the tropical countries and their post-harvest storage constituted a spiny problem (Passam and Noon, 1977; Foua-Bi et al., 1979; Kouadio et al., 2006; Dojnov et al., 2008). So, the Amy A1 and Amy A2 amylases could be used potentially to valorize the tubers and roots starches industrially, what will certainly entail considerably a reduction of the losses post-harvests of these plant matters. To really appreciate the application of theses a-amylases in starch saccharification for syrup production, it is necessary to evaluate their ability to hydrolyse pure starches from local crops. According to the reports of Konsula and Liakopoulou-Kyriakides (2004) and Noda et al.( 2008)the gelatinization process increases the hydrolysis content of starch. Thus, to favour their hydrolysis, theses starches were previously gelatinized. It well known that starch is a major storage product of many economically important tropical crops such as yam, cocoyam, cassava, ginger, maize and millet.

One of the important aspects of this work was the determination of the potentiality of the $\alpha$-amylases Amy A1 and Amy A2 from digestive tract of tropical house cricket $G$ sigillatus to catalyse transglycosylation reactions. Preliminary tests showed that the $\alpha$-amylases were able to synthesise glycosides by reverse hydrolysis reaction using starch as the glycosyl donor and phenol as the glycosyl acceptor. The ability of $\alpha$-amylases from other sources to synthesise glycoside had previously been reported (Park et al., 1999; Larson et al., 2005; Sugimoto et al., 2007; Moreno et al., 2010). It seems that the glycosyl residues transferred in this study were the maltose, maltotriose and probably maltotetraose. Indeed, similar residues transferred was previously described by studying transglycosylation reactions with Aspergillus oryzae a-amylase using starch as glycosyl donor and methanol, ethanol, propanol or butanol as glycosyl acceptor (Larson et al., 2005).

The experimental conditions were optimized in relation to those parameters able to have an influence on the rate of transglycosylation. It must be noted that $\alpha$-amylases purified from the digestive tract of $G$ sigillatus operate at an optimum $\mathrm{pH}$ for transglycosylation reaction of 4.6. This optimum $\mathrm{pH}$ of transglycosylation was different to those of the hydrolysis reactions $(\mathrm{pH} 6.6$ and 7.0) suggesting that $\mathrm{pH} 4.6$ is favourable to the tranglycosylation reactions( Kouadio et al., 2010). These differences could be due to the ionized groups in the active site of the enzymes that enabled hydrolysis and transglycosylation at once (Huber et al., 1983). Thus, at $\mathrm{pH} 4.6$, transglycosylation reactions were favoured but not hydrolysis. Dissimilarities between optimum $\mathrm{pH}$ of hydrolysis and transglycosylation reactions have also been reported for other glycosidases (Huber et al., 1983; Yapi et al, 2007). Time course, glycosyl donor and glycosyl acceptor concentrations of the reactions were also important parameters in the transglycosylation reactions. Indeed, there are optimum values for each parameter optimizing the yields of transglycosylation. The time course of the reaction is particularly important since the products formed during the transglycosylation reaction are used as substrates by the enzyme. $\alpha$-amylases Amy $A 1$ and Amy $A 2$ from the digestive tract of $G$. sigillatus hydrolyzed the products formed.

In optimal conditions, transglycosylation yields of $63.1 \%$ at $6 \mathrm{~h}$ and 51.6 at $7 \mathrm{~h}$ were obtained for Amy A1 and Amy A2 a-amylases, respectively. The transglycosylation yield was higher than those reported with a conventional source of $\alpha$-amylases such as human salivary by The ability of these $\alpha$ amylases to catalyze efficiently synthesis reactions is of great interest because glycosylation is considered 
to be an important method for the structural modification of compounds with useful biological activities (Kandra et al., 2005).

In general, these compounds were used in food and cosmetic materials. Unfortunately, some of these compounds had a strong smell or pungency, or had slight solubility or stability. Otherwise, many of these biologically active compounds included phenolic parts in their structures (Sugimoto et al., 2007). The glycosylation of the phenolic compounds constituted a valuable approach to improve these characteristics for enhancing their usefulness as food and cosmetic ingredients. The data are in agreement with our results, since the transfer products obtained in this work are phenyl glycosides. Moreover, it was important to notice that this work constitute the first report on an insect $\alpha$-amylase with transglycosidase activities.

\section{CONCLUSION}

This report showed clearly that $\alpha$-amylases Amy A1 and Amy A2 from the digestive tract of $G$. sigillatus were able to hydrolyse gelatinized starches from tropical crops such as yam cassava and cocoyam. This demonstrates the potential usefulness of Amy $\mathrm{A} 1$ and Amy A2, as compared to a-amylases from bacteria and fungus, for catalysing the hydrolysis of various starches. Additionally, the interesting properties of these $\alpha$-amylases to catalyse the transfer of glycosyl residues from starch onto phenol could be an alternative to carry out the glycosylation of phenolic compounds. Moreover, the further improvement of these properties to catalyse hydrolysis or transglycosylation reactions by protein engineering could contribute to increase the value of the $\alpha$-amylases Amy A1 and Amy A2 from the digestive tract of $G$. sigillatus.

\section{ACKNOWLEDGEMENTS:}

The authors are grateful to Professor Karim Sory TRAORE (Abobo-Adjamé University, Laboratory of the Sciences of the environment, Unity of Micropolluant, Côte d'Ivoire) for his assistance.

\section{REFERENCES}

Adebiyi, A.O., Adebiyi, A.P and Olaniyi, E. O (2005). Biological studies on albino rats fed with Sorghum bicolor starch hydrolyzed with a-amylase from Rhizopus sp. Afr. J. Biotechnol., 4: 1089-1094.

Amani, NG, Tetchi, FA, Dufour, D and Kamenan, A (2002). A comparative study of the syneresis of yam starches and other modified starches. J. Food Technol. Afr., 7 (1): 4-8.
Bernfeld, P (1995). Amylases alpha and beta. In: Colowick, S.P., Kaplan, N.O. (Eds.), Methods in enzymology, vol. 1. Academic Press, New York, pp: 149-158.

Bornet, F (1992). Technologies des amidons, digestibilité et effets métaboliques. Cahier de Nutrition et de Diététique 27 (3): 170-178.

Brückner, H (1955). Estimation of monosaccharides by the orcinol-sulphuric acid reaction. Biochemical Journal, 60: 200-205.

Colonna, P., Buleon, A and Lemarie, F (1988). Action of Bacillus subtilis alpha-amylase on native wheat starch. Biotechnol. Bioeng., 31: 895-904.

Delpeuch, F and Favier, J.C (1980). Caractéristiques des amidons de plantes alimentaires tropicales: action de l'alpha amylase, gonflement et solubilité. Ann. Technol. Agric., 29 (1): 53-67.

Dojnov, B., Bozi,c N., Nenadovic, V., Ivanovic, J and Vujcic, $\mathrm{J}$ (2008). Purification and properties of midgut amylase isolated from Morimus funereus (Coleoptera: Cerambycidae). Comp. Biochem. Physiol., 149 B: 153160.

Favier, J.C (1969). Etude de la digestibilité "in vitro" de l'amidon de diverses plantes alimentaires du Sud Cameroun: Influence des transformations technologiques sur l'amidon de manioc. Industr. Aliment. Agric., 86: 9-13.

Foua-Bi, K., Demeaux, M and Babacauh, K.D (1979). Pertes sur les ignames au cours du stockage. Causes et méthodes de luttes. Colloque International de Technologie, AUPELF, pp : 22.

Guilbot, A and Mercier, C (1962). Répercussions sur la digestibilité de l'amidon des modifications de sa structure physico-chimique au cours de ses transformations technologiques. Industr. Aliment. Agric., 79: 939-947.

Hamilton, L.M., Kelly, C.T and Fogarty, W.M (1999). Purification and properties of the raw starch degrading alpha-amylase of Bacillus sp.IMD434. Biotechnol. Lett., 21: 111-115.

Huber, R.E., Gaunt, M.T., Sept R.L and Babiak, M.J (1983). Differences in the effects of $\mathrm{pH}$ on the hydrolytic and transgalactosylic reactions of betagalactosidases (Escherichia coli). Canadian J. Biochem. Cell Biol., 61: 198-206.

Kandra, L., Gyémánt, G., Remenyik, J., Ragunath, C and Ramasubbu, N (2005). Transglycosylations catalysed by $\mathrm{Y} 151 \mathrm{M}$ mutant of human salivary alpha-amylase (HSA). Biologia, Bratislava 60 (16): 57-64.

Kolusheva T and Marinova A.(2007). A study of the optimal conditions for starch hydrolysis through thermostable $\alpha$ - amylase. J. Univ. Chem. Technol. Met., 42: 93-96. 
Konsula, Z and Liakopoulou-Kyriakides, M (2004). Hydrolysis of starches by the action of an $\alpha$-amylase from Bacillus subtilis. Proc. Biochem., 39: 1745-1749.

Kouadio, E.J.P., Dué, E.A., Etchian, O.A., SHAW, J and Kouamé, L.P (2010). Purification and Characterization of Two Dimeric a-amylases from Digestive Tract in the Tropical House Cricket Gryllodes sigillatus (Orthoptera: Gryllidae). Aust. J. Basic \& Appl. Sci., 4(10): 5241 5252.

Kouadio, E.J.P., Niamké, S., Kouamé, L.P., Dabonné, S and Kamenan, A (2006). Purification et caractérisation de deux phosphatases acides du tubercule de taro (Xanthosoma sp.) et leur rôle dans conservation Postrécolte. Biotechnol. Agron. Soc. Env., 10(2): 83-91.

Kouame, L P., Dué A., Niamke, S L., Kouame A.F and Kamenan A (2004). Synergism of cockroach (Periplaneta americana) a-amylase and a-glucosidase hydrolysis of starches. Afr. J. Biotechnol. 3 (10): 529533.

Kouamé, L P., Niamké, S., Diopoh J and Colas, B (2001). Transglycosylation reactions by exoglycosidases from the termite Macrotermes subhyalinus. Biotechnol. Lett., 23: 1575-1581

Larsson, J., Svensson, D and Adlercreutz, P (2005). AlphaAmylase-catalysed synthesis of alkyl glycosides. J. Mol. Catal. B., 37: 84-87.

Matsubara, T., Ben Ammar, Y., Anindyawati, T., Yamamoto, S., Ito, K., lizuka, M and Minamiura, N (2004). J. Biochem. Mol. Biol., 37: 422-442.

Moreno, A., Damían-Almazo, J.Y., Miranda, A., SaabRincon, G., Gonzalez, F and López-Munguía, A (2010). Transglycosylation reactions of Thermotoga maritima alpha-amylase. Enzyme Microb. Technol., 46: 331-337.

Nishimura, T., Kometani, T., Takii, H., Terada, $Y$ and Okada, S (1994). Purification and some properties of a-amylase from Bacillus subtilis X-23 that glycosylates phenolic compounds such as hydroquinone. J. Ferm. Bioeng., 78: 31-36.

Noda, T., Takigawa, S., Matsuura-Endo, C., Suzuki, T., Hashimoto, N., Kottearachchi, N. S., Yamauchi, H and Zaidul, I.S.M (2008). Factors affecting the digestibility of raw and gelatinized potato starches. Food Chem., 110: 465-470.
Okolo, B.N., Ezeogu, L.I and Mba, C.N (1995). Production of raw starch digesting Amylase by Aspergillus niger and Bacillus alvei grown on Native starch Sources. J. Sci. Food Agric., 69: 109-115.

Park, Y., Lee, D., Yang, L and , H (1999). Synthesis of glycosides by transglycosylation of a-amylase from soluble starch in water-organic two phase system. Korean J. Microbiol., 35(1): 1-6.

Omemu, A.M., Akpan, I., Bankole, M.O and Teniola, O.D (2005). Hydrolysis of raw tuber starches by amylase of Aspergillus niger AM07 isolated from the soil. Afr. J. Biotechnol., 4:19-25

Passam, H.C and Noon, A.A (1977). Detoriation of yams and cassava during storage. Ann. Appl. Biol., 85: 436440.

Santamaria, R.I., Del Rio, G., Saab, G., Rodriguez, M.E., Soberon, $X$ and Lopez A (1999). Alcoholysis reactions from starch with alpha-amylases. FEBS Letters 452: 346-350.

Sinnott, M (1990). Catalytic mechanism of enzymic glycosyl transfer. Chem. Rev., 90: 1171-1202

Sugimoto, K., Nishimura, T and Kuriki, T (2007). Development of alpha-Arbutin: production at industrial scale and application for a skin-lightening cosmetic ingredient. Trends Glycosci. Glycotechnol., 19 (110): 235-246.

Takeuchi, A., Shimuzu-lbuka, A., Nishiyama, Y., Mura, K., Okada, S., Tokue C and Arai S (2006).Purification and characterization of an a-amylase from Pichia burtonii isolated from the traditional starter"Murcha" in Nepal. Biosc. Biotechnol. and Biochem., 70: 3019-3024.

Thippeswamy, S., Girigowda, K and Mulimani, V H (2006). Isolation and identification of $\alpha$-amylase producing Bacillus sp. from dhal industry waste. Indian J. Biochem. Biophys., 43: 295-298.

Valetudie, J.C., Colonna, P., Bouchet, B and Gallant, D.J (1993). Hydrolysis of tropical tuber starches by bacterial and pancreatic $\alpha$-amylases. Starch/ Stärke, 45: 270-276.

Yapi, D.Y.A., Niamke, S.L and Kouame, L.P (2007). Biochemical characterization of a strictly specific betagalactosidase from the digestive juice of the palm weevil Rhynchophorus palmarum larvae. Entomol.Sci., 10: 343-352. 